\title{
Linkage between the temporal and spatial variability of dissolved organic matter and whole-stream metabolism
}

\author{
S. Halbedel ${ }^{1}$, O. Büttner ${ }^{2}$, and M. Weitere ${ }^{3}$ \\ ${ }^{1}$ Department Lake Research, Helmholtz Centre for Environmental Research - UFZ, Brückstrasse 3a, 39114 Magdeburg, \\ Germany \\ ${ }^{2}$ Department Aquatic Ecosystem Analysis and Management, Helmholtz Centre for Environmental Research - UFZ, \\ Brückstrasse 3a, 39114 Magdeburg, Germany \\ ${ }^{3}$ Department River Ecology, Helmholtz Centre for Environmental Research - UFZ, Brückstrasse 3a, 39114 Magdeburg, \\ Germany
}

Correspondence to: S. Halbedel (susanne.halbedel@ufz.de)

Received: 25 November 2012 - Published in Biogeosciences Discuss.: 17 December 2012

Revised: 15 June 2013 - Accepted: 3 July 2013 - Published: 19 August 2013

\begin{abstract}
Dissolved organic matter (DOM) is an important resource for microbes, thus affecting whole-stream metabolism. However, the factors influencing its chemical composition and thereby also its bio-availability are complex and not thoroughly understood. It was hypothesized that whole-stream metabolism is linked to DOM composition and that the coupling of both is influenced by seasonality and different land-use types. We tested this hypothesis in a comparative study on two pristine forestry streams and two non-forestry streams. The investigated streams were located in the Harz Mountains (central Europe, Germany). The metabolic rate was measured with a classical two-station oxygen change technique and the variability of DOM with fluorescence spectroscopy. All streams were clearly net heterotrophic, whereby non-forestry streams showed a higher primary production, which was correlated to irradiance and phosphorus concentration. We detected three CDOM components $(\mathrm{C} 1, \mathrm{C} 2, \mathrm{C} 3)$ using parallel factor (PARAFAC) analysis. We compared the excitation and emission maxima of these components with the literature and correlated the PARAFAC components with each other and with fluorescence indices. The correlations suggest that two PARAFAC components are derived from allochthonous sources ( $\mathrm{C} 1, \mathrm{C} 3)$ and one is derived autochthonously $(\mathrm{C} 2)$. The chromophoric DOM matrix was dominated by signals of humic-like substances with a highly complex structure, followed by humic-like, fulfic acids, lowmolecular-weight substances, and with minor amounts of
\end{abstract}

amino acids and proteins. The ratios of these PARAFAC components $(\mathrm{C} 1: \mathrm{C} 2, \mathrm{C} 1: \mathrm{C} 3, \mathrm{C} 3: \mathrm{C} 2)$ differed with respect to stream types (forestry versus non-forestry). We demonstrated a significant correlation between gross primary production (GPP) and signals of autochthonously derived, lowmolecular-weight humic-like substances. A positive correlation between $P / R$ (i.e. GPP/daily community respiration) and the fluorescence index FI suggests that the amount of autochthonously produced DOM increased overall with increasing GPP. In accordance with the coupling between DOM and the metabolism, our data also indicate that the composition of DOM is subject to seasonal fluctuations.

We concluded that temporal and spatial differences in DOM composition are driven by whole-stream metabolism, in addition to pronounced effects coming from allochthonous sources.

\section{Introduction}

Dissolved organic matter (DOM) is a complex mixture of soluble organic compounds that vary in their reactivity and ecological role (Jaffé et al., 2008; Wetzel, 1992). Both the molecular weights and the chemical groups of DOM can vary strongly, e.g. from low weight carbohydrates to complex aromatic compounds. Depending on its chemical composition, it largely controls heterotrophic production in streams (Wetzel, 1992; Tank et al., 2010). 
The biochemical composition of DOM is mainly determined by its source (Ohno et al., 2007). DOM released from autochthonous sources like living aquatic plants - i.e. vascular plants, mosses, phototrophic biofilms and phytoplankton - is generally of lower molecular weight and contains fewer aromatic rings than compounds leached from terrestrial soils and litter (Barrón et al., 2012; Lapierre and Frenette, 2009; Stepanauskas et al., 2000). Even though terrigenous organic matter consists mostly of highly complex molecules with higher aromaticity (Graeber et al., 2012), it can also consist of low molecular compounds; terrestrial plants and fungi produce easily available exudates that can enter the aquatic ecosystem and therefore influence the quality of DOM (McKnight, 2001; Jaffé et al., 2008). However, most streams in the Northern Hemisphere are net heterotrophic; i.e. they are net sinks of organic matter rather than sources (Marcarelli et al., 2011). Thus, community respiration must be subsidized by organic inputs from allochthonous sources.

Land use is generally thought to regulate DOM composition in streams (Graeber et al. 2012), but the underlying regulation mechanisms are not clear and the results are sometimes contrasting. Wilson and Xenopoulus (2009), for example, showed that increasing areas of cropland and decreasing areas of wetland lead to an increase in the contribution of recently produced organic matter in a Canadian catchment. In another study Williams et al. (2010) found that DOM in agriculturally affected streams was more labile and available for microbial turnover than DOM in wetland streams, which supported low rates of microbial activity. On the other hand, in Germany, Graeber et al. (2012) documented an increase of DOM dominated by structurally complex humic-like substances in agricultural lowland streams compared to streams draining forest and wetland. The reasons for such contradicting results are not clear. However, rising agricultural land use leads to changes in light conditions and to an increase in the nutrient import from the terrestrial environment, thus affecting gross primary production (GPP) and community respiration (CR) (Bernot et al., 2010; Gücker et al., 2009). Autochthonous organic matter production becomes more important with increasing light availability (Finlay et al., 2011; Minshall, 1978). If stream metabolism and DOM availability are assumed to be linked, it is important to study both together when planning carbon turnover studies. But integrated investigations into the coupling of metabolism and DOM composition are rare.

Just as environmental factors like light availability and temperature change seasonally, so too does metabolism (Acuña et al., 2004). Hence, DOM composition should also display seasonal variability if coupled to biological processes. However, all studies known to us to date have not found any seasonal variability for DOM composition (cp. Graeber et al., 2012). On the other hand, hydrodynamic factors like discharge events are known to be main drivers of the temporal variability of DOM (Graeber et al., 2012; Royer and David, 2005). Hydrodynamic factors are also known to affect stream metabolism (Acuña et al., 2004). If investigations into seasonality of DOM composition are planned, hydrodynamic changes that can overlie metabolism effects should be avoided.

The biochemical characteristics of DOM can be related to its optical properties (Mueller et al., 2012). The individual fluorescence and light absorption of the optical fraction (the chromophoric dissolved organic matter, $\mathrm{CDOM}$ ) can be used to trace the compositional changes of DOM (Jaffé et al., 2008; Fellman et al., 2010). Especially the fluorescence characterization of DOM, known as excitation emission matrices (EEMs), provides proxies for the source, the redox state, and the biological availability of CDOM (Jaffé et al., 2008; Fellman et al., 2010). Parallel factor analysis (PARAFAC) splits data matrices of the EEMs into underlying fluorescence appearance and is therefore suitable for distinguishing between the different fluorophores, which represent molecular fractions of DOM (Stedmon and Bro, 2008). In combination with established fluorescence indices, it is possible to distinguish for example between different humic-like components and protein-like substances, as well as between autochthonous or allochthonous DOM (Fellman et al., 2010; Mueller et al., 2012).

The aim of the present study was to test the hypothesis that signals of DOM composition and whole-stream metabolism are correlated in a spatio-temporal context. Consequently, DOM composition is subject to seasonal changes and varies between stream types parallel to variations in stream metabolism. To test this hypothesis, we combined the classical two-station oxygen change technique for wholestream metabolism studies with fluorescence spectroscopy as an optical finger-print technique for the detection of CDOM composition.

\section{Material and methods}

\subsection{Study area}

Our study sites are located in the south-eastern part of the Harz Mountains, in central Europe, Germany (Fig. 1). This area lies in the temperate zone of the Northern Hemisphere and has, in general, a continental climate. Typical for this upland are rather wet summers and cold winters. The bedrock in the upper mountains consists of a Paleozoic upland overlaid with brown earth and bleaching clay, based on loess layer and silt or silt rubble. The geological basis of the middle and upper mountains consists of argillaceous shale and greywacke. Depending on the bedrock and the associated rubble layer, alkaline brown earth, podsol-brown earth or podsols can be found there. Due to the wet climate gley and fens are also located in this area (Karste et al., 2011).

We selected four small streams (Zillierbach, Ochsenbach, Hassel, Rappbode) for our investigations. Keeping our main 

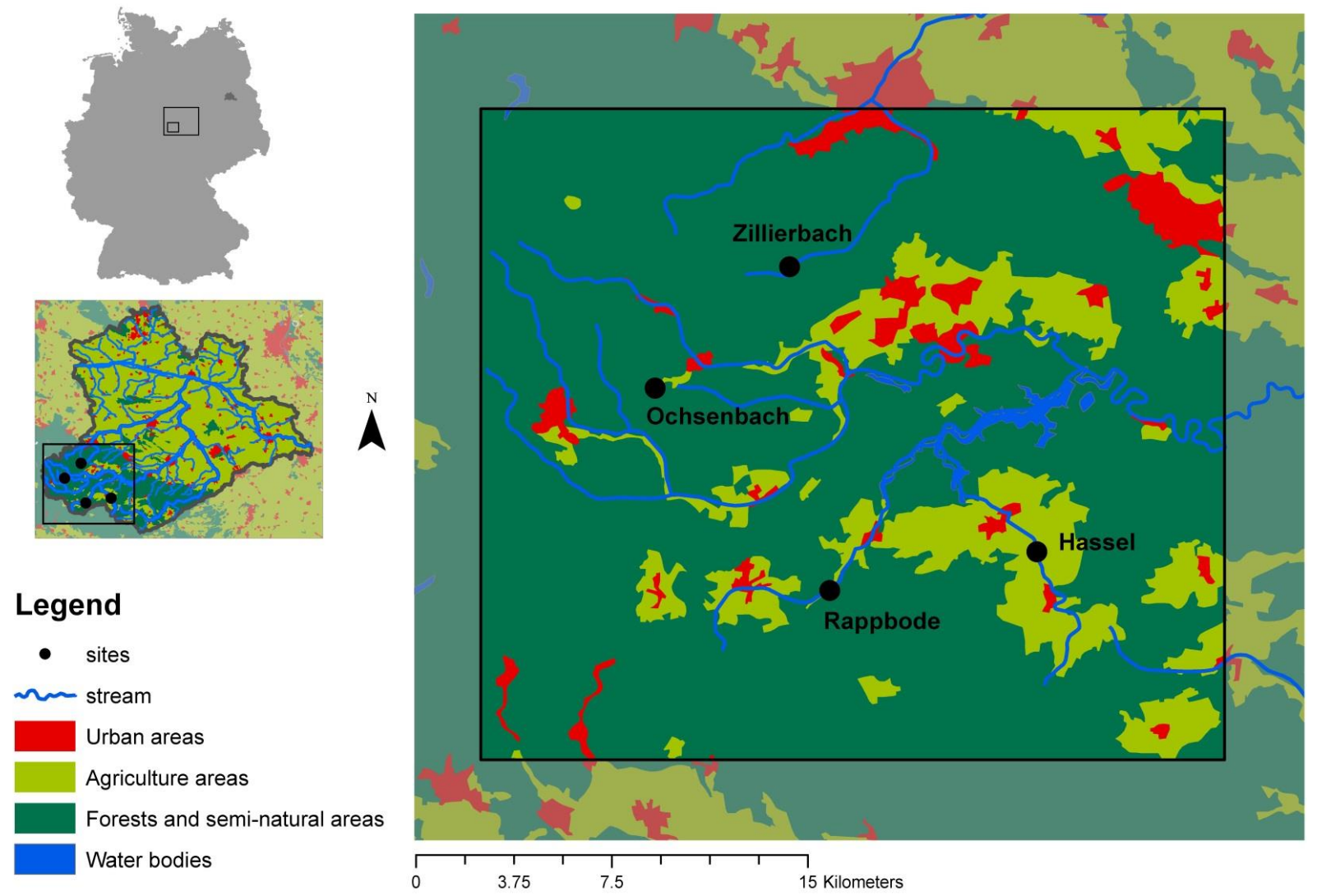

Fig. 1. Map of the investigation area with indicated sampling stations and land-use types.

research question in mind we looked for streams with different land-use types, especially with different light regimes. While both pristine streams Ochsenbach and Zillierbach are almost exclusively shaded by alder trees $(100 \%$ forest in the catchment), the other streams are surrounded by open space with little or no vegetation for the whole stretch taken for metabolism measurements and to the vast majority upstream of the investigation area. These streams have the following land-use types in their catchment: Rappbode has $6 \%$ agriculture (cattle), $1 \%$ urban areas, and $93 \%$ semi-natural areas (open space with little or no vegetation, groves and scrub or herbaceous vegetation) and forest, and Hassel has $14 \%$ agriculture areas (cattle), $3 \%$ urban areas, and $83 \%$ semi-natural areas and forest.

\subsection{Sampling and sampling preparation}

For each stream we selected a reach that was representative for the respective stream. The selected stream reaches were classified according to their tree canopies into "forestry" (Zillierbach, Ochsenbach) and "non-forestry" streams (Rappbode, Hassel). An overview of the sampling periods and detailed stream reach characteristics is given in Table 1.

All detailed investigations as described in the following were performed in spring, summer and autumn 2011. In win- ter 2012, chemical and selected physical parameters were measured only. In this season, all streams had water temperatures of between 0 and $2{ }^{\circ} \mathrm{C}$ (Table 1). They were all under a dense ice and snow cover, and the upper soil layers were frozen. Under these conditions accurate metabolism studies are not possible and community metabolism is probably very low. Each sampling period lasted for four days. For better comparability of different sampling periods and to avoid signals from extreme hydraulic events, we investigated streams only at base flow, where a nearly constant water level over the whole sampling period was guaranteed.

All water samples for further optical and chemical analysis were collected between 11:00 and 13:00 (UTC), directly under the water surface, in the thalweg. By considering possible turnover processes and time variations the following sampling procedure was applied: samples were taken at both stations of the stream reach, under consideration of the travel time, twice in a row, on up to two days. This procedure allows the direct comparison of daily changes in water chemistry and metabolism. If necessary, all water samples were filtered and fixed directly in the field. For further DOC analysis and for optical analysis, the water samples were filtered through Whatmann glass fibre filters $(0.7 \mu \mathrm{m}, \mathrm{GF} / \mathrm{F})$. The samples were acidified with $\mathrm{H}_{2} \mathrm{SO}_{4}(1: 4)$ for total phosphorus (TP) analysis, and samples for nitrogen analysis were fixed with 
Table 1. The general stream characteristics of the investigated streams*.

\begin{tabular}{|c|c|c|c|c|c|c|c|c|c|c|c|c|c|}
\hline & & & sample period & $\begin{array}{r}\text { reach } \\
\mathrm{m}\end{array}$ & $\begin{array}{r}\text { depth } \\
\mathrm{cm}\end{array}$ & $\begin{array}{r}\text { width } \\
\mathrm{m}\end{array}$ & $\begin{array}{r}\text { surface } \\
\mathrm{m}^{2}\end{array}$ & $\mathrm{~ms}^{-1}$ & $\mathrm{Ls}^{Q-1}$ & 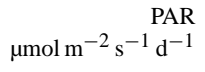 & $\begin{array}{c}T \\
{ }^{\circ} \mathrm{C}\end{array}$ & $\begin{array}{r}\text { Cond. } \\
\mu \mathrm{S} \mathrm{cm}^{-1}\end{array}$ & $\mathrm{pH}$ \\
\hline \multirow{8}{*}{ 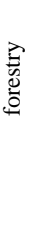 } & Zillierbach & spring & 16.-19.04.2011 & 126 & 12 & 1.1 & 140 & 0.03 & 4 & 261011 & 6.9 (SD 2.3) & 183 (SD 2) & $7.6(\mathrm{SD} 0.04)$ \\
\hline & & summer & 26.-28.07.2011 & 50 & 8 & 1.0 & 52 & 0.01 & 1 & 18814 & $12.5(\mathrm{SD} 1.2)$ & 209 (SD 7) & 7.7 (SD 0.07) \\
\hline & & fall & 14. -18.10 .2011 & 50 & 11 & 1.1 & 55 & 0.02 & 2 & 24195 & $6.6(\mathrm{SD} 0.7)$ & 220 (SD 4) & 7.7 (SD 0.02) \\
\hline & & winter & 14.02 .2012 & 50 & n.d. & n.d. & n.d. & n.d. & n.d. & n.d. & $0.0(\mathrm{SD} 0.0)$ & 185 (SD 1) & $7.3(\mathrm{SD} 0.04)$ \\
\hline & Ochsenbach & spring & 07.-09.05.2011 & 86 & 10 & 1.1 & 98 & 0.04 & 4 & 379887 & $9.4(\mathrm{SD} 2.7)$ & 145 (SD 6) & $7.3(\mathrm{SD} 0.31)$ \\
\hline & & summer & 02.-04.08.2011 & 86 & 7 & 1.1 & 90 & 0.03 & 2 & 45460 & 13.4 (SD 1.6) & 154 (SD 4) & $7.3(\mathrm{SD} 0.05)$ \\
\hline & & fall & 22. -25.10 .2011 & 86 & 10 & 1.1 & 97 & 0.04 & 4 & 29913 & 4.8 (SD 1.3) & 153 (SD 5) & $7.4(\mathrm{SD} 0.02)$ \\
\hline & & winter & 14.02 .2012 & 86 & n.d. & n.d. & n.d. & n.d. & n.d. & n.d. & $2.0(\mathrm{SD} 0.0)$ & $150(\mathrm{SD} 0)$ & $7.4(\mathrm{SD} 0.01)$ \\
\hline \multirow{8}{*}{ 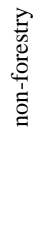 } & Rappbode & spring & 28.05.-30.05.2011 & 135 & 25 & 1.9 & 259 & 0.06 & 30 & 728935 & $14.1(\mathrm{SD} 2.0)$ & 198 (SD 2) & 7.7 (SD 0.09) \\
\hline & & summer & 22.- -25.08 .2011 & 88 & 26 & 2.1 & 181 & 0.04 & 23 & 469435 & $15.9(\mathrm{SD} 1.0)$ & 238 (SD 4) & $7.8(\mathrm{SD} 0.15)$ \\
\hline & & fall & $05 .-08.11 .2011$ & 88 & 28 & 1.9 & 166 & 0.07 & 37 & 82373 & $5.8(\mathrm{SD} 0.6)$ & 208 (SD 0) & $7.9(\mathrm{SD} 0.13)$ \\
\hline & & winter & 16.02 .2012 & 88 & n.d. & n.d. & n.d. & n.d. & n.d. & n.d. & $0.5(\mathrm{SD} 0.0)$ & 167 (SD 0) & $7.6(\mathrm{SD} 0.03)$ \\
\hline & Hassel & spring & 06.-08.06.2011 & 40 & 7 & 0.9 & 37 & 0.02 & 1 & 494307 & 17.5 (SD 2.7) & 359 (SD 7) & $7.6(\mathrm{SD} 0.08)$ \\
\hline & & summer & 22. -25.08 .2011 & 40 & 12 & 1.1 & 46 & 0.04 & 5 & 469435 & $15.6(\mathrm{SD} 1.1)$ & 299 (SD 1) & $7.6(\mathrm{SD} 1.07)$ \\
\hline & & fall & 12.-15.11.2011 & 50 & 10 & 1.1 & 54 & 0.04 & 3 & 367250 & $0.8(\mathrm{SD} 0.6)$ & 429 (SD 8) & $7.8(\mathrm{SD} 0.02)$ \\
\hline & & winter & 16.02.2012 & 50 & n.d. & n.d. & n.d. & n.d. & n.d. & n.d. & $0.6(\operatorname{SD} 0.1)$ & $183(\mathrm{SD} 0)$ & $7.4(\mathrm{SD} 0.03)$ \\
\hline
\end{tabular}

* The presented data are mean values of the physical, chemical and geomorphological data measured during each field campaign. The following abbreviations were used: $v=$ calculated velocity, $Q=$ discharge, PAR = photosynthetic active radiation, $T=$ temperature, Cond. = conductivity, n.d. $=$ not determined. Standard deviations $(\mathrm{SD})$ are shown in parenthesis.

$\mathrm{HgCl}_{2}$. All water samples (filtered and non-filtered) were transferred into acid-rinsed and combusted brown glass bottles, and stored cool $\left(6^{\circ} \mathrm{C}\right)$ until further analyses. All fluid samples where measured not later than 2 days after sampling.

The parameter conductivity, $\mathrm{pH}$ and turbidity were measured in situ at station one and two of the respective stream reach with multiparameter probes (YSI 6600-V2, and Hydrolab DS5X). The logging interval was set to 10 or $15 \mathrm{~min}$.

\subsection{Metabolism studies}

Metabolism was estimated with the upstream-downstream diurnal dissolved oxygen change technique (Odum, 1956; Hauer and Lamberti, 2007). For each stream one representative stream reach was defined with lengths ranging from 40 to $135 \mathrm{~m}$ (Table 1). Stream length was adapted to discharge. It was the aim to create travel times that are sufficient for metabolism calculation (ideally between 20 and $40 \mathrm{~min}$ ). Metabolism was measured using oxygen measurements at both ends of the reach at one-minute intervals, for approximately 60 hours. Thus, metabolism was detected on two days for each stream, in the respective season. Oxygen $\left(\mathrm{O}_{2}\right)$ and temperature $(T)$ were measured with DOptoLogger (ZEBRA-TECH LTD). Loggers were calibrated in the laboratory with two-point calibration at room temperature $\left(20^{\circ} \mathrm{C}\right)$. A correction factor was determined from test measurements at different temperatures in the laboratory and from simultaneous measurements in the stream at the end of each experiment. Changes in dissolved oxygen between station one and two $(\Delta \mathrm{DO})$ were calculated after travel time $(t)$, corrected for T, pressure, lateral inflow $(I)$, mean depth $(z)$ and reaeration $\left(k_{\mathrm{O}_{2}}\right)$, and were then considered as the result of metabolic processes (gross primary production, GPP, and community respiration, $\mathrm{CR}_{24}$ ) (Hauer and Lamberti, 2007; Hall and Tank, 2005).
Mean width $(w)$ was determined together with $z$ with cross-sectional profiles following the description given in Gordon et al. (2008). Atmospheric pressure was measured two times per day with a barometer. The actual pressure was interpolated. Travel time $(t)$ and the reaeration coefficient $\left(k_{\text {propane }}\right)$ between both stations were measured by injecting a volatile (propane) and a conservative tracer $(\mathrm{NaCl})$ into the stream. The distance between the salt injection point and station one was always equal to ten times the average stream width. The conservative tracer was injected into the stream water by a slug (cp. Bales and Nardi, 2007). For the determination of $I, Q$, and $t$, the changes in conductivity were measured at one-second intervals with YSI probes (YSI $600 \mathrm{XLM})$ at stations one and two. We calculated the velocity ( $v$ ) by dividing $Q$ by $w$ multiplied by $z$. After $t$ was determined, propane was bubbled with a constant pressure of 3 bar into the stream using 3 diffusors. Propane was sampled at station one and two and at four additional stations in between. These additional samples were used for a control of the correct propane decrease between both stations. All samples were taken in triplicate. First samples at the upstream station (station one) were taken after the propane-enriched water had been flowing for in minimum of one $t$ from station one to two. Sampling then commenced at station one and all further samples were taken following the flow until station two was reached. This ensures that the same water body was sampled. A sample of $12 \mathrm{~mL}$ of water was taken with a syringe in the thalweg from directly under the water surface and injected into $20 \mathrm{~mL}$ serum vials. We took care to avoid turbulences during injection. Vials were immediately crimped and stored at $4^{\circ} \mathrm{C}$. Within one week after collection the equilibrated headspace was analyzed in the laboratory by flame ionization detection on a SRI 8610C gas chromatograph. We used hydrogen as a carrier gas. Reaeration $\left(k_{\text {propane }}\right)$ was calculated according to the following equation: 
$k_{\text {propane }}=\frac{1}{t} \cdot \ln \left(\frac{G_{1} \cdot Q_{2}}{G_{2} \cdot Q_{1}}\right)$,

whereby $G_{1}$ and $G_{2}$ are the propane concentrations at stations one and two, and $Q_{1}$ and $Q_{2}$ are the discharges measured at station one and two of the stream reach (cp. Demars et al., 2011). $k_{\text {propane }}$ was converted to $k_{\mathrm{O}_{2}}$ using the factor 1.39 (Rathbun et al., 1978).

Parallel to the oxygen measurements, irradiance (photosynthetic active radiation, PAR) was monitored with a spherical quantum sensor (LI-193, LI-COR) which was installed circa 1 meter above the water surface, at a representative place. The actual irradiance was logged by the minute.

The calculations of the metabolism rate $\left(\Delta \mathrm{DO}^{\prime}\right)$ for one day were made from two successive night measurements (PAR $<1 \mu \mathrm{mol} \mathrm{m}^{-2} \mathrm{~s}^{-1}$ ) and from the period in between $\left(\mathrm{PAR} \geq 1 \mu \mathrm{mol} \mathrm{m}^{-2} \mathrm{~s}^{-1}\right)$. The calculation of $\Delta \mathrm{DO}^{\prime}$ followed Eq. (2):

$\Delta \mathrm{DO}^{\prime}=\left(\Delta \mathrm{DO}+R_{\mathrm{f}}\right) \cdot z \cdot \frac{\mathrm{d} t}{t}$,

whereby $R_{\mathrm{f}}$ is the absolute reaeration flux (in $\mathrm{g} \mathrm{m}^{-3}$ ) in the reach at one $t, z$ is the mean depth, and $\mathrm{d} t$ is the detection interval in minutes. $R_{\mathrm{f}}$ was calculated as follows:

$R_{\mathrm{f}}=C_{\mathrm{def}} \cdot k_{\mathrm{O}_{2}}^{\prime} \cdot t$,

whereby $C_{\text {def }}$ is the average reach saturation deficit (mg L ${ }^{-1}$ ), and $k_{\mathrm{O}_{2}}^{\prime}$ belongs to the temperature corrected $k_{\mathrm{O}_{2}}$ (Elmore and West, 1961). The daily respiration rate was then computed with the following equation:

$\mathrm{CR}_{24}=\frac{\sum_{t_{0}}^{t_{1}} \Delta \mathrm{DO}^{\prime}}{\alpha_{1}+\alpha_{2}} \cdot m$,

whereby $t_{0}$ describes the sunset (first time with PAR $<1 \mu \mathrm{mol} \mathrm{m}^{-2} \mathrm{~s}^{-1}$ ) and $t_{1}$ represents sunrise (first time with PAR $\left.\geq 1 \mu \mathrm{mol} \mathrm{m}{ }^{-2} \mathrm{~s}^{-1}\right), \alpha_{1}$ is the number of $\Delta \mathrm{DO}$ values in the first night and $\alpha_{2}$ is the number of $\Delta \mathrm{DO}$ values in the second night, and $m$ is the number of measurements during one day pending on the logging interval (in this case $m=1440)$. GPP was then calculated as follows:

$\mathrm{GPP}=\frac{\mathrm{CR}_{24}}{m} \cdot n-\sum_{t_{1}}^{t_{0}} \Delta \mathrm{DO}^{\prime}$,

with $n$ as the number of $\Delta \mathrm{DO}$ between $t_{1}$ and $t_{0}$. All metabolism rates were converted to rates per unit area by dividing the area of stream bottom between the two stations. A detailed description of the calculation procedure applied here is given by Hauer and Lamberti (2007).

For the ecological characterization of the investigated streams we calculated the indices $P / R$ and net ecosystem production (NEP). $P / R$ is the ratio of GPP to $\mathrm{CR}_{24}$.
$P / R$ values $>1$ indicate that the stream is rather phototrophic, and values $<1$ indicate a rather heterotrophic ecosystem. NEP was calculated by subtracting $\mathrm{CR}_{24}$ from GPP. This index is usually used to describe the source of energy for the whole-stream metabolism. If NEP values are positive, the investigated stream has a positive energy budget, whilst negative values indicate a net energy loss from this ecosystem (Mulholland et al., 2001).

The standard deviation for estimation of metabolism (GPP as well as $\mathrm{CR}_{24}$ ) is lower than $0.2 \mathrm{~g} \mathrm{~m}^{-2} \mathrm{~d}^{-1}$, based on a Monte Carlo simulation $(n=500$, at each of the values at four different sites) regarding the uncertainties in measurements within a $10 \%$ error range (continuous measurements of $\mathrm{O}_{2}, T$, pressure). Regarding the uncertainties connected to the parameters $t, z$ and $k_{\text {propane }}$ we used a variance decomposition method (Saltelli et al., 2008) and applied it to four different data sets varying the parameters in a $10 \%$ range around the "true" estimated value (uniform distribution, $n=1024)$. We found that $\mathrm{z}$ is responsible for $53 \%$ of variance in GPP calculation and $k_{\text {propane }}$ accounts for $47 \%$ of GPP variation. The uncertainties in $t$ have minor relevance for estimation of GPP. A similar picture emerged regarding estimation of $\mathrm{CR}_{24}$ except that for the smallest stream, Ochsenbach, the portion of responsibility for the output variation changed to $24 \%, 11 \%$ and $65 \%$ for $t, z$ and $k_{\text {propane }}$, respectively. The observed standard deviation during variance decomposition is lower than $0.5 \mathrm{~g} \mathrm{O}_{2} \mathrm{~m}^{-2} \mathrm{~d}^{-1}$ for GPP and $\mathrm{CR}_{24}$ estimation.

\subsection{Chemical and optical analysis}

Total phosphorus (TP) was measured with the ammonium molybdite spectrometric method. Nitrite $\left(\mathrm{NO}_{2}^{-}\right)$, nitrate $\left(\mathrm{NO}_{3}^{-}\right)$, and ammonium $\left(\mathrm{NH}_{4}^{+}\right)$were photometrically determined with the segmented flow technique DIN EN ISO 13395. The measurements of DOC, spectral absorption and EEM analysis were carried out in parallel. The DOC concentration was measured by high-temperature combustion using a DIMATOC ${ }^{\circledR} 2000$. The absorption by CDOM was measured from 200 to $800 \mathrm{~nm}$ using a Hach Lange DR 5000 spectrophotometer and a $1 \mathrm{~cm}$ quartz cuvette. Deionized water was used as a blank. An additional background correction was applied by subtracting the average absorbance value per $\mathrm{nm}$ from 700 to $800 \mathrm{~nm}$ from the rest of the spectrum. We calculated the absorption coefficients by multiplying the optical density by 2.303 /cuvette path length. From these data the absorption was computed at $375 \mathrm{~nm}\left(a_{375}\right)$, which is a predictor of the total amount of DOM. It can be used to test the relationship between CDOM and DOC, which generally makes up the main fraction in a natural DOM matrix (Stedmon et al., 2006). Fluorescence measurements were done using a Skalar fluorescence spectrophotometer. The excitationemission matrix (EEM) was obtained by combining a series of emission scans made from 260 to $385 \mathrm{~nm}$ ( $5 \mathrm{~nm}$ steps), while excitation at wavelengths ranged from 240 to $360 \mathrm{~nm}$ 
( $5 \mathrm{~nm}$ steps). We tested the absorption between 300 and $800 \mathrm{~nm}$ to decide whether the data must be corrected regarding the inner-filter effect (Mobed et al., 1996; Stedmon and Bro, 2008). Also, dilution tests were made to assess single samples. After we were not able to find a quenching effect we decided that the EEM spectra need no correction. Instrumental changes and biases were checked by using two quinine stocks with different concentrations. The EEMs were Raman calibrated with MilliQ water as a blank prior to further computation.

The following indices were calculated based on EEM spectra: (i) the two-dimensional fluorescence index (FI), which provides information about the source of DOM (McKnight, 2001); (ii) the freshness index $(\beta: \alpha)$, which indicates if the DOM was produced recently $(\beta)$ or is decomposed $(\alpha)$ (Parlanti et al., 2000), and its origin (Huguet et al., 2009); and (iii) the humification index (HIX) which is an indicator of the extent of humification and biological degradation (Ohno, 2002; Wickland et al., 2007). The emission spectra of fluorescing molecules shift toward longer wavelengths (due to lower $\mathrm{H}: \mathrm{C}$ ratios) as humification of DOM proceeds. Thus, higher values indicate a higher degree of humification as well as lower microbial availability. Based on instrumental limitations, FI was calculated as the ratio of emission intensity at a wavelength of $450 \mathrm{~nm}$ to that of $500 \mathrm{~nm}$, obtained with an excitation at $360 \mathrm{~nm}$. In the original work done by McKnight et al. (2001), the aforementioned ratio was calculated for an excitation at $370 \mathrm{~nm} . \beta: \alpha$ was used as an additional indicator of the DOM source to avoid biases based on this adjustment. This index was computed as the ratio of the emission intensity at $380 \mathrm{~nm}$ divided by the highest detected emission intensity between 420 and $435 \mathrm{~nm}$, all obtained for an excitation at $310 \mathrm{~nm}$ (Parlanti et al., 2000; Wilson and Xenopoulos, 2009; Fellman et al., 2010). $\beta: \alpha$ values $>1$ indicate a rather autochthonous origin, and values $<0.6$ indicate primarily allochthonous sources (Huguet et al., 2009; Williams et al., 2010). The HIX index was calculated by dividing the peak area under the emission spectra between 435 and $480 \mathrm{~nm}$ with the peak area under the emission spectra between 300 and $445 \mathrm{~nm}$, both at $255 \mathrm{~nm}$ excitation (Zsolnay et al., 1999).

The whole EEM data set was examined using PARAFAC. PARAFAC is a special form of the multivariate statistic where a structure of redundant excitation $(\mathrm{Ex})$ and emission (Em) maxima is extracted from a large data set (Stedmon and Bro, 2008). The structure of groups of Ex/Em maxima can be used to identify the component groups by comparing them with literature findings (Table 2).

\subsection{Statistical analysis}

The PARAFAC analysis was carried out in MATLAB (version R2011a) using the "N-way toolbox for MATLAB" (Anderson and Bro, 2000) and following the tutorial of Stedmon and Bro (2008). The whole data set was outlier corrected in accordance with this tutorial.
With regard to metabolism data, we excluded the Hassel summer data from all data sets when correlating metabolism parameters with other values because stream metabolism in the Hassel was clearly affected in summer by discharge events and by heavy modification by cows, both overlaying seasonal background signals. A non-parametrical test (Spearman's rank correlation) was used to test the significance of correlations. The $p$ values in Table 3 are considered statistically significant at $p<0.0042$ since twelve tests were applied for this data set (Bonferroni correction for multiple testing). We tested the significance of the differences between both land-use types by summing the data over all seasons. Normal distribution for our data could not be shown (twoway KS test). Therefore we assessed whether the pre-defined stream types ("forestry" and "non-forestry") are significantly different from each other in terms of CDOM composition using the Wilcoxon rank-sum test. Because of the restricted number of replicates, it was not possible to test the significance of the seasonal differences statistically. All statistical analyses were performed with MATLAB, Sigma Plot 12.0, or Microsoft Excel 2010.

\section{Results}

\subsection{Geophysical and geochemical stream characteristics}

Seasonal changes in chemical characteristics, corresponding air temperature and precipitation data are shown (Figs. 2 and 3). Table 1 gives an additional overview of geochemical and physical stream characteristics, including mean daily irradiance values. All streams were neutral with respect to $\mathrm{pH}$. The conductivity was generally low to moderate. With $429 \mu \mathrm{S} \mathrm{cm}^{-1}$ the Hassel had the highest conductivity in autumn. The parameters T, PAR and Q followed the typical seasonal variability in most of the streams (Table 1). Only the Hassel had the highest discharge and slightly decreased temperatures in summer, which is a result of the previous rainy period (Fig. 2).

Overall, the Hassel had the highest nutrient concentrations, i.e. on average $0.66 \mathrm{mg} \mathrm{L}^{-1} \mathrm{NH}_{4}^{+}, 0.10 \mathrm{mg} \mathrm{L}^{-1} \mathrm{NO}_{2}$, $2.07 \mathrm{mg} \mathrm{L}^{-1} \mathrm{NO}_{3}, 4.78 \mathrm{mg} \mathrm{L}^{-1} \mathrm{DOC}$, and $0.14 \mathrm{mg} \mathrm{L}^{-1} \mathrm{TP}$. The concentration of DOC and total phosphorus were thereby highest in summer (Fig. 3). At $5.06 \mathrm{mg} \mathrm{L}^{-1}$ the Rappbode revealed also high DOC concentrations in this season. Both non-forestry streams - Hassel and Rappbode - had generally higher phosphorus concentrations. The mean phosphorus values ranged from 0.022 to $0.396 \mathrm{mg} \mathrm{L}^{-1}$ for the Hassel and from 0.011 to $0.054 \mathrm{mg} \mathrm{L}^{-1}$ for the Rappbode. In spring, fall and winter the mean DOC concentrations in the Hassel were in the range of those measured in the Zillierbach over these seasons. In contrast to these streams, the Ochsenbach revealed the lowest overall DOC concentration with a mean of $1.58 \mathrm{mg} \mathrm{L}^{-1}$. The lowest nitrate concentrations were 
Table 2. The ecological definitions for the different PARAFAC components (Fig. 4)*.

\begin{tabular}{|c|c|c|c|}
\hline Component & $\begin{array}{l}\text { Excitation } \\
\text { peak }\end{array}$ & $\begin{array}{l}\text { Emission } \\
\text { peak }\end{array}$ & Description of sources and biochemical functions \\
\hline $\mathrm{C} 1$ & $355(260)$ & 435 & $\begin{array}{l}\text { UVC humic-like, high-molecular-weight humic and aromatic, widespread, highest in } \\
\text { wetlands and forest; UVA humic-like, fulvic acid, widespread; terrestrial plant material or } \\
\text { soil organic matter }{ }^{1,2} \text {. }\end{array}$ \\
\hline $\mathrm{C} 2$ & 315 & $370(390,510)$ & $\begin{array}{l}\text { UVA humic-like, low molecular weight, associated with biological activity, common in } \\
\text { marine environments, found in wastewater, wetland, and agricultural environments; rather } \\
\text { autochthonous and from microbial processing, but also terrestrial sources (plant material } \\
\text { and soil organic matter) }{ }^{3,1,4,5} \text {; Ex/Em } 315 / 510 \text { is unknown. }\end{array}$ \\
\hline $\mathrm{C} 3$ & 290 & $450(335)$ & $\begin{array}{l}\text { Amino acids, free of bound in proteins, fluorescence resembles free tryptophan; } \\
\text { humic-like substance, high molecular weight, widespread, found in wetlands } \\
\text { and in forests; terrestrially derived, autochthonous produced and from microbial } \\
\text { processes } 5,4,1,2,6 \text {. }\end{array}$ \\
\hline
\end{tabular}

\footnotetext{
* Abbreviations are EX=excitation and EM=emission. The ecological role of the modelled components was reproduced by comparing their Ex/Em maxima with the literature. The following literature was used: ${ }^{1}$ Cory and McKnight (2005), ${ }^{2}$ Coble et al. (1998), ${ }^{3}$ Stedmon et al. (2003), ${ }^{4}$ Stedmon and Markager (2005), ${ }^{5}$ Murphy et al. (2006), 6 Schmidt et al. (2009).
}

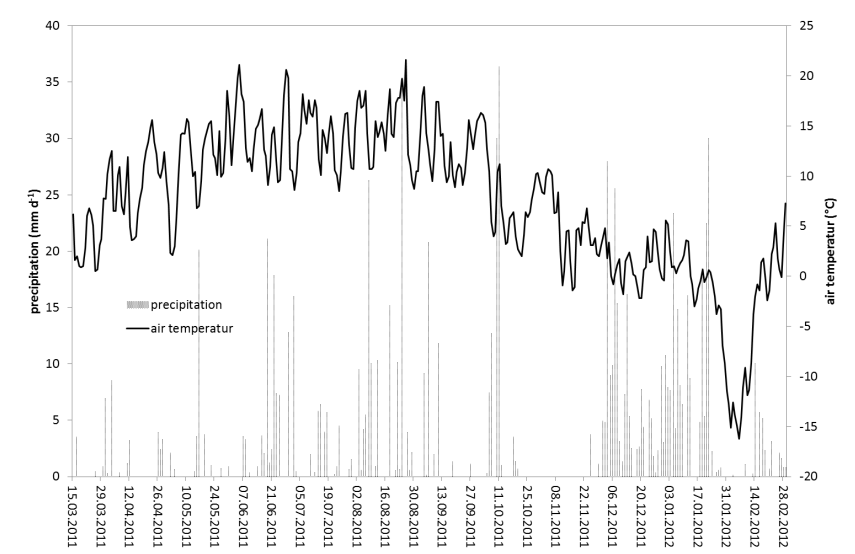

Fig. 2. Overview of the air temperature (black line) and the precipitation (bars) over the whole sampling period. The weather data were representative data from the weather station in Braunlage, Harz Mountains, Germany.

observed in the Rappbode, where the mean values over all seasons were $0.22 \mathrm{mg} \mathrm{L}^{-1}$.

\subsection{The characterization of the CDOM composition}

A significant linear relationship between $a_{375}$ and DOC was found $\left(R^{2}=0.64, p<0.001\right)$ indicating that changes in DOM amount were largely explained by changes in DOC concentration. Most of the detected fluorophores are reproducible by comparison of their excitation and emission maxima with the recent literature. The components were detected with PARAFAC analysis using the EEMs from all four streams ( $n=100$, after outlier selection $n=98$, Fig. 4). The PARAFAC components are termed C1, C2 and C3 in the fol- lowing. A detailed description of them is presented in Table 2 .

To obtain a more detailed picture on the origin of the fluorophores we considered the correlations between the PARAFAC component which is known to be terrigenous (C1) and the other components $(\mathrm{C} 2, \mathrm{C} 3)$, where the origin was not clearly defined in the literature. All single PARAFAC components $(\mathrm{C} 1, \mathrm{C} 2, \mathrm{C} 3)$ were significantly correlated with each other (Fig. 5). We assessed the origin and the degree of biochemical degradation (humification) of each component also by testing the relationships between PARAFAC components and the calculated DOM indices: $\beta: \alpha$, FI, and HIX (see Table 3 for details). Only weak to moderate relationships can be detected when correlating the single components with different indices: $\mathrm{C} 1$ correlated moderately with HIX and weakly with FI, but not with $\beta: \alpha$; 2 correlated moderately with FI and $\beta: \alpha$, but not with HIX; and C3 correlated weakly with HIX, FI, but not with $\beta: \alpha$. The correlation between HIX and PARAFAC components indicated that there was a general increase in humification if $\mathrm{C} 1$ and $\mathrm{C} 3$ increased. The correlations between FI and PARAFAC components indicated that there was a general increase in terrigenously derived DOM if any of the PARAFAC components increased. Furthermore, with an increase of C2 the amount of autochthonously derived and freshly produced DOM increased, indicated by the positive correlations with $\beta: \alpha$. We tested whether the component ratios $(\mathrm{C} 1: \mathrm{C} 3, \mathrm{C} 1: \mathrm{C} 2$, $\mathrm{C} 3$ : $\mathrm{C} 2$ ) have closer relationships to HIX, FI, and $\beta: \alpha$ (Table 3 ). We found the following relationships: $\mathrm{C} 1: \mathrm{C} 3$ correlated strongly with HIX, and not with FI or $\beta: \alpha$; the ratio $\mathrm{C} 1$ : C2 correlated positively with HIX, and negatively with FI and $\beta: \alpha$; and $\mathrm{C} 3: \mathrm{C} 2$ correlated negatively with FI and $\beta: \alpha$, but not with HIX. We infer from this that the degree of humification is higher for $\mathrm{C} 1$ than for $\mathrm{C} 2$ and $\mathrm{C} 3$. $\mathrm{C} 1$ seems 


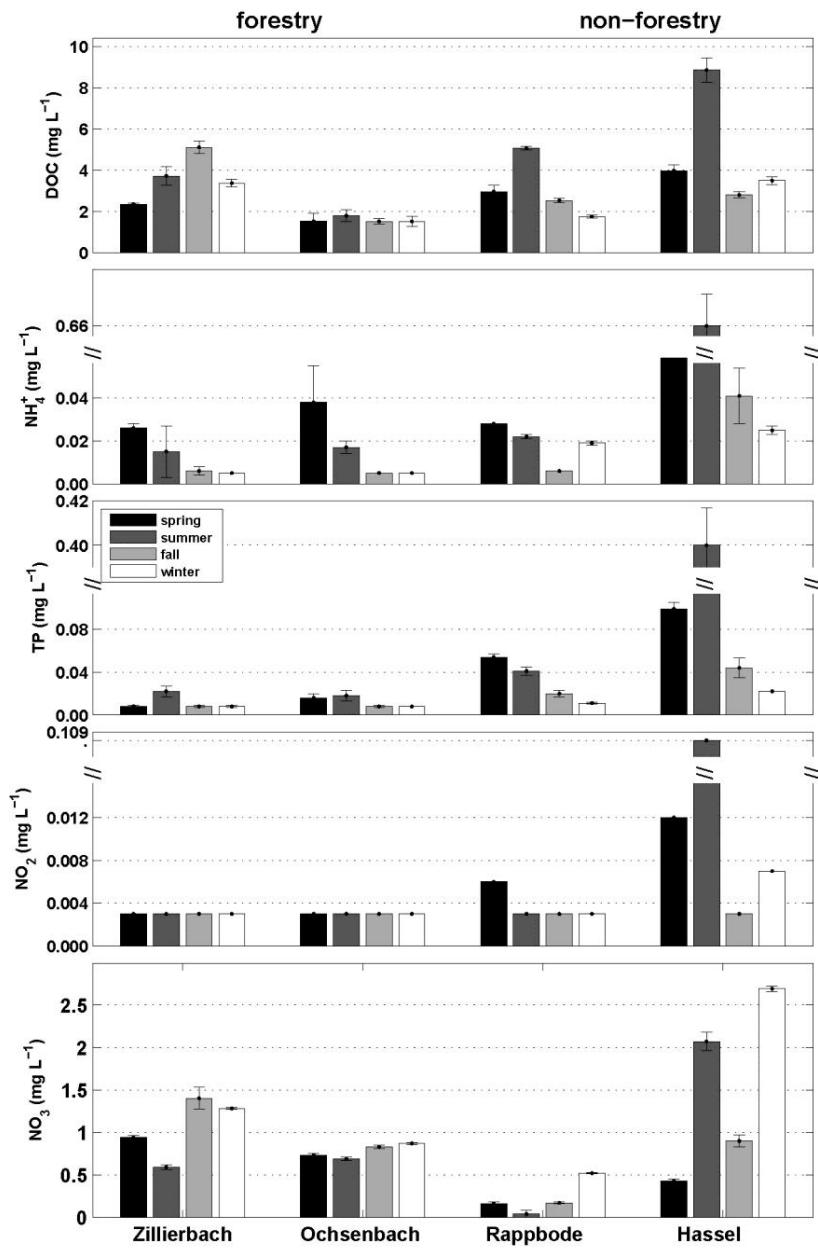

Fig. 3. Overview of the chemical characteristics of the investigated streams. The presented values are mean values $( \pm \mathrm{SD})$ of the chemical data measured during each field campaign. Following parameters are shown: $\mathrm{DOC}=$ dissolved organic carbon, $\mathrm{NH}_{4}^{+}=$ammonium, $\mathrm{TP}=$ total phosphorus, $\mathrm{NO}_{2}=$ nitrite and $\mathrm{NO}_{3}=$ nitrate.

to be more refractory than $\mathrm{C} 3$ and $\mathrm{C} 2$. It is clearly indicated that $\mathrm{C} 2$ was recently produced and is derived from an autochthonous source. We checked this once again by correlating $(\mathrm{C} 1+\mathrm{C} 3) / \mathrm{C} 2$ with the fluorescence indices. This ratio correlated positively with HIX, and negatively with FI, and $\beta: \alpha$, indicating again a general increase of humification and a decrease of the amount of autochthonously derived, recently produced DOM with decreasing C2.

\subsection{Temporal and spatial variability of the CDOM composition}

To assess the spatial and temporal variability of the PARAFAC components we used ratios $(\mathrm{C} 1: \mathrm{C} 2, \mathrm{C} 1: \mathrm{C} 3$, $\mathrm{C} 3$ : C2) sorted into land-use groups ("forestry", "nonforestry"). Differences found between forestry and nonforestry streams were significant if summing the ratios from
Table 3. Spearman's rank correlation between PARAFAC components, component ratios and fluorescence indices*.

\begin{tabular}{lrr}
\hline correlations & $r$ & $p$ \\
\hline $\mathrm{C} 1 / \mathrm{HIX}$ & 0.54 & $<0.001$ \\
$\mathrm{C} 1 / \mathrm{FI}$ & 0.45 & $<0.001$ \\
$\mathrm{C} 1 / \beta: \alpha$ & 0.16 & 0.120 \\
$\mathrm{C} 2 / \mathrm{HIX}$ & 0.29 & 0.005 \\
$\mathrm{C} 2 / \mathrm{FI}$ & 0.68 & $<0.001$ \\
$\mathrm{C} 2 / \beta: \alpha$ & 0.50 & $<0.001$ \\
$\mathrm{C} 3 / \mathrm{HIX}$ & 0.47 & $<0.001$ \\
$\mathrm{C} 3 / \mathrm{FI}$ & 0.43 & $<0.001$ \\
$\mathrm{C} 3 / \beta: \alpha$ & 0.23 & 0.030 \\
$\mathrm{C} 1: \mathrm{C} 3 / \mathrm{HIX}$ & 0.79 & $<0.001$ \\
$\mathrm{C} 1: \mathrm{C} 3 / \mathrm{FI}$ & 0.23 & 0.020 \\
$\mathrm{C} 1, \mathrm{C} 3, \beta: \alpha$ & -0.17 & 0.110 \\
$\mathrm{C} 1: \mathrm{C} 2 / \mathrm{HIX}$ & 0.53 & $<0.001$ \\
$\mathrm{C} 1: \mathrm{C} 2 / \mathrm{FI}$ & -0.57 & $<0.001$ \\
$\mathrm{C} 1: \mathrm{C} 2 / \beta: \alpha$ & -0.87 & $<0.001$ \\
$\mathrm{C} 3: \mathrm{C} 2 / \mathrm{HIX}$ & 0.11 & 0.285 \\
$\mathrm{C} 3: \mathrm{C} 2 / \mathrm{FI}$ & -0.76 & $<0.001$ \\
$\mathrm{C} 3: \mathrm{C} 2 / \beta: \alpha$ & -0.78 & $<0.001$ \\
$(\mathrm{C} 1,+\mathrm{C} 3): \mathrm{C} 2 / \mathrm{HIX}$ & 0.43 & $<0.001$ \\
$(\mathrm{C} 1+\mathrm{C} 3): \mathrm{C} 2 / \mathrm{FI}$ & -0.65 & $<0.001$ \\
$(\mathrm{C} 1+\mathrm{C} 3): \mathrm{C} 2 / \beta: \alpha$ & -0.87 & $<0.001$ \\
\hline
\end{tabular}

* The following indices are used: HIX = humification index; FI = fluorescence index; $\beta: \alpha=$ freshness index.

a whole year $(\mathrm{C} 1: \mathrm{C} 2 p<0.001 ; \mathrm{C} 1: \mathrm{C} 3 p=0.045 ; \mathrm{C} 3: \mathrm{C} 2$ $p<0.001)$. It was not possible to test the significance of differences between single seasons. The temporal changes of the different PARAFAC component ratios $(\mathrm{C} 1: \mathrm{C} 2, \mathrm{C} 1: \mathrm{C} 3$, $\mathrm{C} 3$ : C2) are presented (Fig. 6). C1 was the dominant component in all streams over the whole year. This is shown especially for the forestry streams, where the means of $\mathrm{C} 1$ : $\mathrm{C} 2$ as well as of $\mathrm{C} 1: \mathrm{C} 3$ were above 2 (median). However, the CDOM composition in the forestry streams differed from that found in the non-forestry streams. In non-forestry streams the values for $\mathrm{C} 1: \mathrm{C} 2$ were below the $\mathrm{C} 1: \mathrm{C} 2$ medians found for forestry streams over the whole year. In winter the $\mathrm{C} 1: \mathrm{C} 2$ ratios increased in non-forestry streams up to 2.3 , but did not reach the level of the higher $\mathrm{C} 1: \mathrm{C} 2 \mathrm{ra}-$ tios of forestry streams. In forestry streams $\mathrm{C} 1: \mathrm{C} 2$ values spread highest in summer, with ratios ranging from 1.5 to 3.5. Thus the lowest $25 \%$ of the values are comparable with ratios found for the non-forestry streams, whilst $25 \%$ of the higher values are located above 2.5. These higher values were also found in forestry streams in spring, summer and autumn. In contrast to non-forestry streams in winter the $\mathrm{C} 1: \mathrm{C} 2 \mathrm{ra}$ tios are lower in forestry streams.

With values ranging from 0.6 to $1, \mathrm{C} 3$ : C2 in non-forestry streams were below the ratios found in forestry streams (1.1, median value over all seasons). There the highest values were found in spring (1.3). In winter C3 : C2 dropped to a median of 1 in forestry streams. Therefore, $\mathrm{C} 2$ was in general highest 

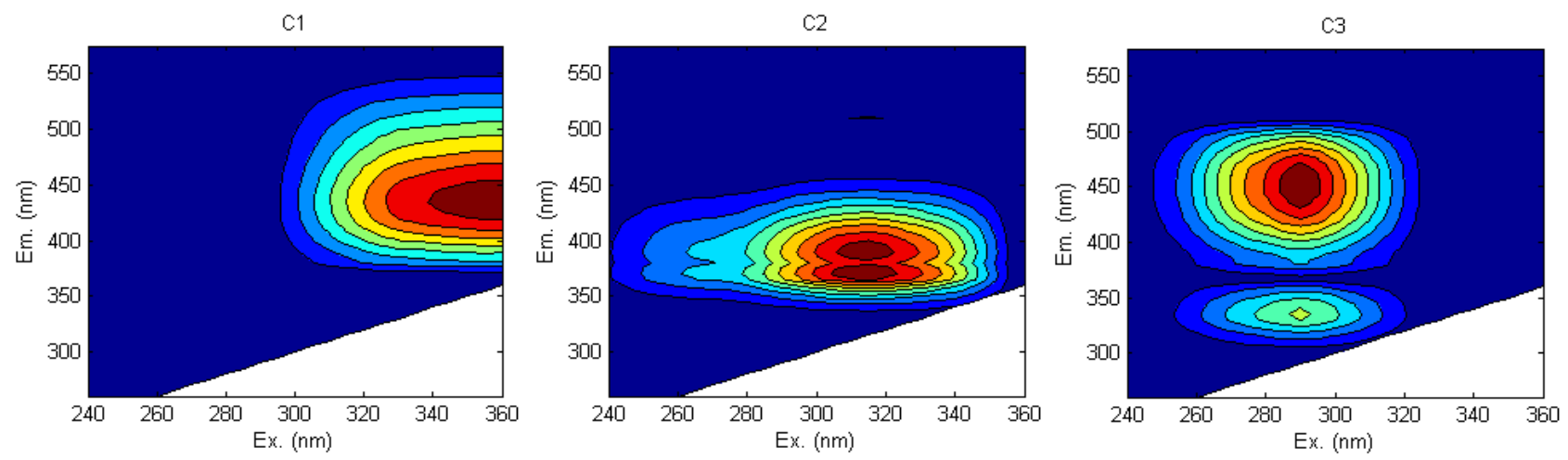

Fig. 4. Contour plots describing the fluorescence characteristic of three components, modelled based on 98 samples with the PARAFAC analysis. The detailed description of component 1,2 and 3 (C1, C2, and C3) can be found in Table 2.
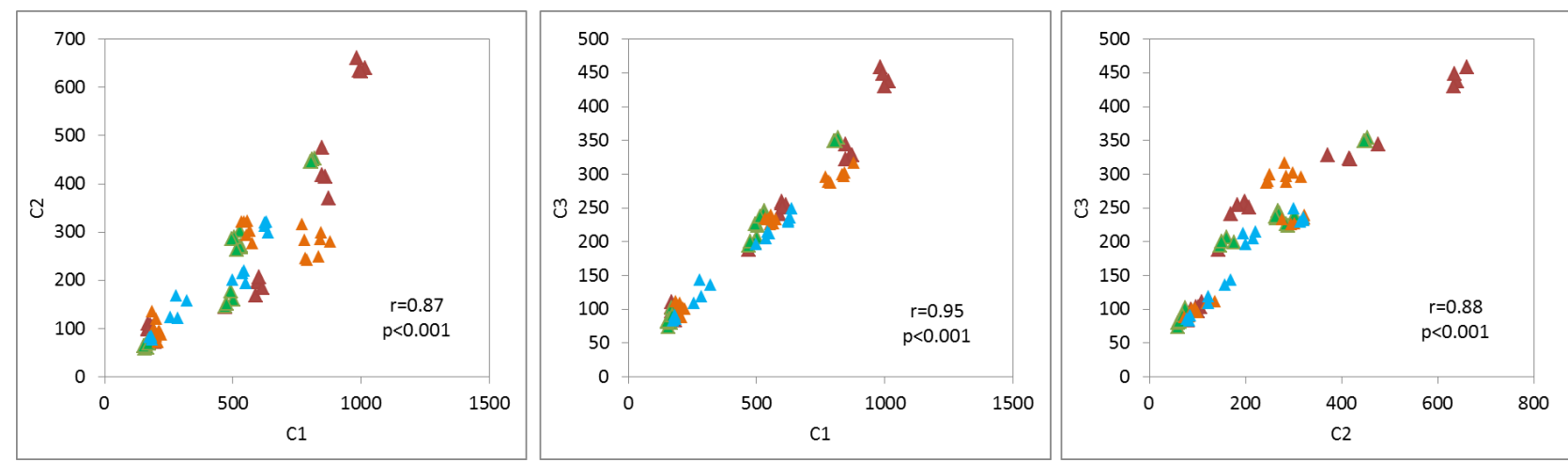

Fig. 5. Spearman's rank correlation between the PARAFAC components $\mathrm{C} 1, \mathrm{C} 2$ and $\mathrm{C} 3$ (Table 2). $\mathrm{C} 1$ : $\mathrm{C} 2$ (left), $\mathrm{C} 1: \mathrm{C} 3$ (middle), $\mathrm{C} 3$ : $\mathrm{C} 2$ (right). Correlations are based on single values $(n=98)$. Colours of triangles indicate spring (green), summer (red), autumn (orange), and winter (blue). All correlations are highly significant $(p<0.001)$.

in non-forestry streams, indicated by median $\mathrm{C} 3: \mathrm{C} 2$ values of 0.8 , whilst $\mathrm{C} 2$ plays a minor role in the $\mathrm{CDOM}$ mixture of forestry streams. In forestry streams $\mathrm{C} 3$ seems to be more important (median $\mathrm{C} 3: \mathrm{C} 2>1$ ).

\subsection{Whole-stream metabolism and its linkage to CDOM composition}

The results of the metabolism studies are summarized in Fig. 7. $P / R$ values for all streams were below 1 , indicating the general heterotrophic character of all streams. With a mean $P / R$ ratio of 0.05 , forestry streams (Zillierbach, Ochsenbach) were more heterotrophic than nonforestry streams (Hassel, Rappbode), which had a mean $P / R$ ratio of 0.3 . Especially the Rappbode showed highest $P / R$ ratios from on average 0.28 to 0.51 . The $P / R$ is influenced by changes in both GPP and $\mathrm{CR}_{24}$. NEP was negative in all streams, indicating that metabolism generally relies on additional external, terrestrially derived DOM. With average values of $-5.4 \mathrm{~g} \mathrm{O}_{2} \mathrm{~m}^{-2} \mathrm{~d}^{-1}$ the Zillierbach and the Hassel had the lowest NEP. In contrast to this, the NEP values for the Ochsenbach and especially for the Rappbode were clearly above the average NEP of the other streams. With mean values ranging from -0.42 to $-3.79 \mathrm{~g} \mathrm{O}_{2} \mathrm{~m}^{-2} \mathrm{~d}^{-1}$ the Rappbode had the highest NEP in comparison to all other streams.

All streams showed the highest GPP and $\mathrm{CR}_{24}$ values in spring. In this season the average estimated GPP in forestry streams was $0.77 \mathrm{~g} \mathrm{O}_{2} \mathrm{~m}^{-2} \mathrm{~d}^{-1}$ and in non-forestry streams $3.19 \mathrm{~g} \mathrm{O}_{2} \mathrm{~m}^{-2} \mathrm{~d}^{-1}$. Zillierbach and Hassel had the highest $\mathrm{CR}_{24}$, with mean rates above $9 \mathrm{~g} \mathrm{O}_{2} \mathrm{~m}^{-2} \mathrm{~d}^{-1}$. In comparison to the spring data, the metabolic activity was clearly decreased in all streams during summer, as indicated by the lower GPP and $\mathrm{CR}_{24}$ values. In fall $\mathrm{CR}_{24}$ increased again in the pristine forestry streams and in the Hassel, with different magnitudes. This increasing $\mathrm{CR}_{24}$ leads to very low average $P / R$ values ranging from 0.01 to 0.07 . The mean GPP increased in this season only in the Hassel (from 0.10 to $0.54 \mathrm{~g} \mathrm{O}_{2} \mathrm{~m}^{-2} \mathrm{~d}^{-1}$ ) and to a less pronounced extent in the Zillierbach (from 0.11 to $0.15 \mathrm{~g} \mathrm{O}_{2} \mathrm{~m}^{-2} \mathrm{~d}^{-1}$ ). We found a tight correlation $(r=0.83, p<0.001)$ between GPP and PAR. GPP correlated also with TP $(r=0.84, p<0.001)$.

We tested whether there is a linkage between estimates of whole-stream metabolism and the proxies for DOM 

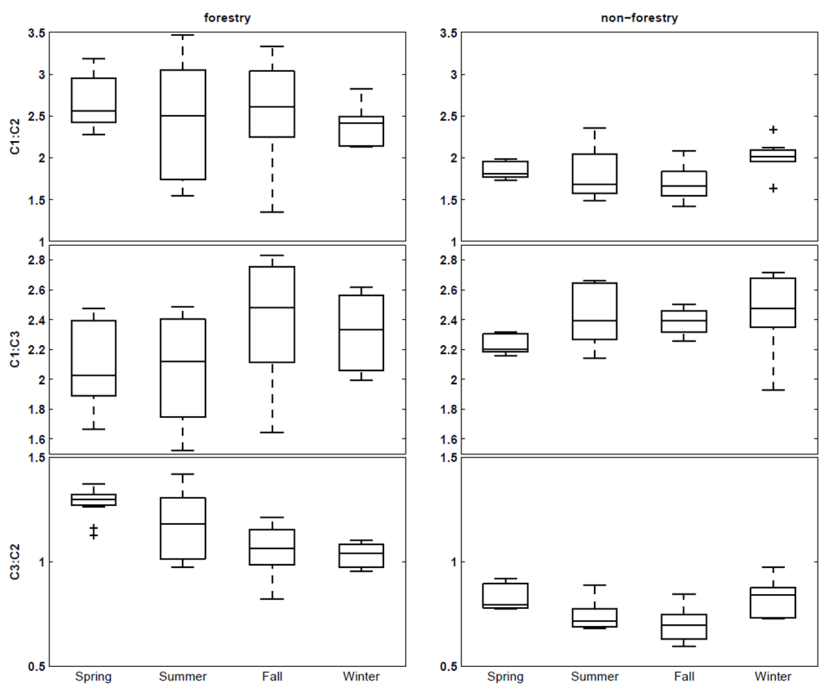

Fig. 6. Boxplots of seasonal changes of the DOM composition expressed as changes in the component ratios and sorted for the different land-use types (forestry versus non-forestry streams). Boxplots are based on single values $(n=98)$.

composition (Fig. 8). We found a significant correlation between $P / R$ and FI $(r=0.532 ; p=0.013)$, indicating a linkage between the trophic status of the streams $(P / R)$ and the source of DOM. Furthermore, significant correlations between $P / R$ and $\mathrm{C} 2(r=0.527 ; p=0.014)$, as well as between GPP and C2 ( $r=0.497 ; p=0.021)$ were demonstrated. Thus with an increase of primary production, especially in comparison to community respiration, the general amount of autotrophically derived organic matter increased as well as the PARAFAC component $\mathrm{C} 2$, which consists of a less complex, labile humic-like substance.

\section{Discussion}

\subsection{Differences between forestry and non-forestry streams in terms of their CDOM composition}

Highly complex, humic-like CDOM (C1) was dominant in all streams. It indicates that terrestrial DOM had the main proportion of DOM in all investigated streams. This finding confirms earlier results from other studies (Graeber et al., 2012; Mueller et al., 2012). We assumed that changes in land use should affect CDOM composition. CDOM composition was clearly linked to different land-use types (forestry, nonforestry). Both component ratios $\mathrm{C} 1: \mathrm{C} 2$ and $\mathrm{C} 3: \mathrm{C} 2$ were higher in forestry streams than in non-forestry streams. In contrast, $\mathrm{C} 1$ : C3 was slightly higher in non-forestry streams than in forestry streams. These findings suggest that lowmolecular-weight, labile, autochthonously derived CDOM (C2) plays a larger role in non-forestry streams than in forestry streams. It also suggests that allochthonous less re-

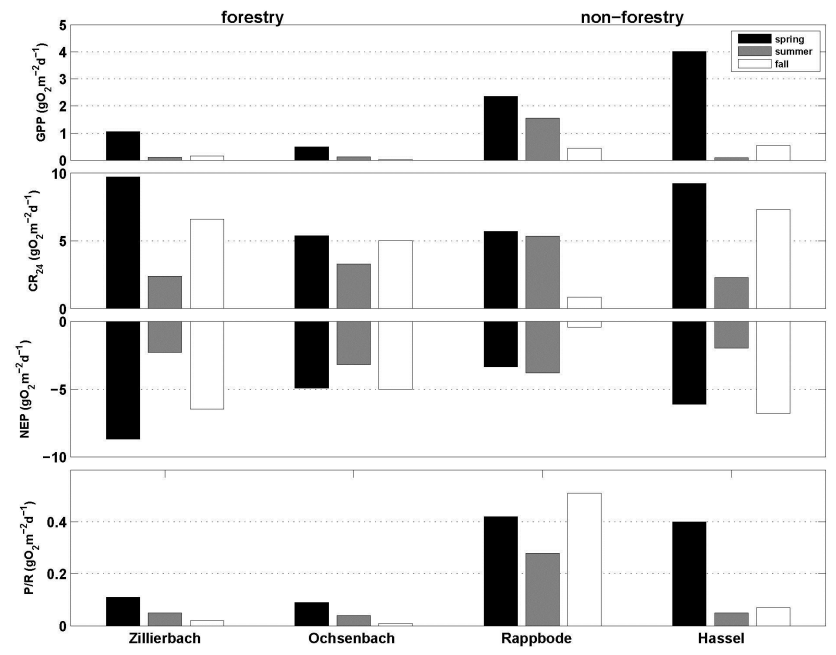

Fig. 7. Summary of the estimated metabolism data. The data are given as mean values $(n=2)$. Abbreviations are GPP $=$ gross primary production, $\mathrm{CR}_{24}=$ daily community respiration, $\mathrm{NEP}=$ net ecosystem production (positive $\mathrm{NEP}=$ net energy production, negative $\mathrm{NEP}=$ net energy loss) $P / R=$ ratio of GPP and $\mathrm{CR}_{24}$ with $P / R>1=$ phototrophic and $P / R<1=$ heterotrophic.

fractory organic matter ( $\mathrm{C} 3$, including proteins) is more relevant in forestry environments. In a study of water sources in a forested catchment, it was found that groundwater exported more protein-like substances, whereas soil layers export more humic-like DOM (Inamdar et al., 2012). Consequently we assume that forestry streams investigated in our study were generally more influenced by groundwater than non-forestry streams. The non-forestry streams probably were mostly fed with water from adjacent soil layers. The authors Graeber et al. (2012) came to similar conclusions in their study of German lowlands. They investigated the effects of land use on DOM composition in headwater streams and found an increase of structural complexity (increasing HIX) and low redox state of DOM in agricultural environments, which are also non-forestry. In contrast, Wilson and Xenopoulos (2009) found DOM of low structural complexity was related to a high percentage of agricultural area in Canada, which supports our findings. Plausible explanations for such contradicting results could be different soil types, as Graeber et al. (2012) stated. However, Graeber et al. (2012) investigated streams draining agricultural areas with changing vegetation cover. The DOM composition of these streams is affected by soil degradation processes and altering hydrological situations. DOM quality and quantity in agricultural streams were already shown to be positively related to discharge (Blann et al., 2009). Our non-forestry streams are running through open-canopy areas and draining crop and forest areas with continuous vegetation cover. Furthermore, all streams were investigated at base flow to avoid hydraulic effects on the DOM composition. We assume that, especially at base flow, stream-internal biogeochemical processes 

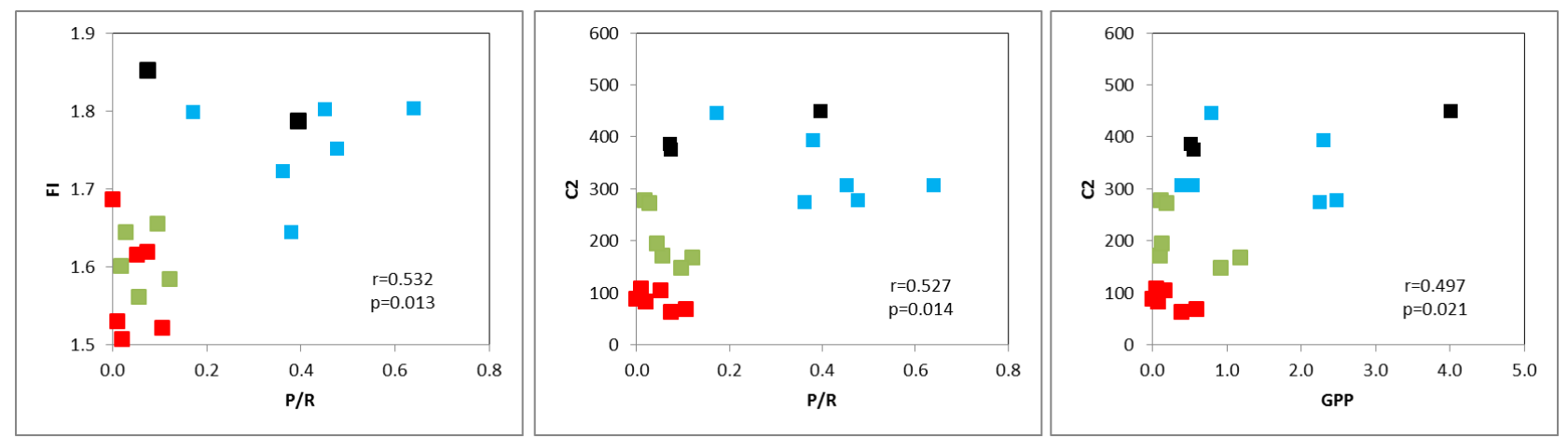

Fig. 8. Spearman's rank correlation between $P / R$ and FI, $P / R$ and $\mathrm{C} 2$, and GPP and $\mathrm{C} 2$. With an increasing phototrophic character $(P / R)$ and a general increase of primary production (GPP) also the amount of autochthonously derived DOM increased (as indicated by increases in FI and C2). Colours of squares indicate Zillierbach (green), Ochsenbach (red), Rappbode (blue), and Hassel (black).

are increasingly relevant, in particular in sun-exposed nonforestry streams.

\subsection{How the metabolic rate of forestry and non-forestry streams changes over time}

All streams considered here were heterotrophic and had a negative metabolic balance, as indicated by $P / R$ values below 1 and negative NEP values, which is in line with the usual situation in small streams (Mulholland et al., 2001). Thus, they have to cover their metabolic requirements by allochthonous nutrient supply in particular (cp. Marcarelli et al., 2011).

We expected differences in the metabolic rate between forestry and non-forestry streams and at different seasons. Pronounced seasonality and between-stream differences of the metabolism could be detected. Particularly the Rappbode was more phototrophic than the forestry streams. But also the Hassel showed higher $P / R$ values in spring. In the forestry streams, $P / R$ values decreased from spring to summer. This can be explained by the diminished PAR at the water surface with increasing forest canopy in the dense alder forests. GPP was correlated with PAR and TP, which can explain the general lower GPP values in the forestry streams. The generally tight coupling between irradiance, phosphorus and primary production was shown earlier (Acuña et al., 2010; Young and Huryn, 1999; Mulholland et al., 2001 and many more). It is feasible that, according to Liebig's law of minimum, GPP in streams is coupled to the most limited resource, which in our case seems to be TP and PAR.

Even though all streams were investigated at base flow, the non-forestry streams were affected by previous discharge events during the summer period. In detail, in both nonforestry streams the metabolic rate was diminished in summer, which results in a decrease of $P / R$. The humid weather in the summer period leads to a multitude of high-discharge events that affected the community negatively and thereby also the metabolic processes in the non-forestry streams. In addition, also extensive ranching along the Hassel should have affected the metabolic processes of this stream in summer. This stream was directly investigated after a herd of cows had been grazing on the grassland there. The high ammonium and phosphorus concentrations in summer can be explained by the fact that the cows were allowed to go directly into the Hassel to drink and to urinate. It appears to be possible that the extreme nutrient increase after cow grazing could have had pronounced effects on the whole-stream biota. Furthermore, disturbances by discharge events are generally known to reduce primary production and respiration rapidly (Acuña et al., 2004; Houser et al., 2005; Mulholland et al., 2005).

\subsection{The linkage between DOM and metabolism}

Changes in DOM composition can generally affect its availability for metabolic rate and, vice versa, community metabolism can affect DOM composition by consumption or primary production of DOM (Wickland et al., 2007; Finlay et al., 2011; Minor et al., 2006; Williams et al., 2010; Barrón et al., 2012; Lapierre and Frenette, 2009; Stepanauskas et al., 2000). We hypothesized that such dependencies lead to a pronounced correlation between measures for metabolism and DOM composition under natural conditions in a spatiotemporal context. In fact, we were able to demonstrate that DOM composition is generally linked to metabolism, e.g. by correlations between fluorescence indices (FI), C2 and $P / R$. In addition, we found $\mathrm{C} 2$ also correlated directly to GPP. Thus, especially GPP but also $P / R$ was linked to the autotrophically derived, labile fraction of the DOM composition. This finding is further highlighted by the fact that both $\beta / \alpha$ and FI were negatively linked to the ratio $(\mathrm{C} 1+\mathrm{C} 3) / \mathrm{C} 2$. We concluded that $\mathrm{C} 2$, which was mainly indicated as autotrophically derived, low-molecular-weight, humic-like substance, is produced by phototrophic or photochemical processes (i.e. photodegradation). 
Autochthonously produced (Barrón et al., 2012) and allochthonously derived DOM can theoretically support the heterotrophic turnover (Berggren et al., 2010). Two PARAFAC components were found that originated from allochthonous sources $(\mathrm{C} 1, \mathrm{C} 3)$ and one component that originated from an autochthonous source (C2). We expected that an increase of less refractory organic matter $(\mathrm{C} 2, \mathrm{C} 3)$ can support heterotrophic activity and therefore also the further degradation of organic matter (Finlay et al., 2011; Matheson et al., 2012; Ogawa et al., 2001). C3 seems to be less aromatic and humificated than $\mathrm{C} 1$ (indicated by lower HIX values) and thus less recalcitrant, but was not correlated with $\mathrm{CR}_{24}$. Even though $\mathrm{C} 2$ correlated negatively with HIX, suggesting a higher microbial availability, we found no correlation to community respiration. Thus our hypothesis could not be confirmed. On the other hand, it is well known that changes in DOM matrix driven by photochemical or photosynthetic processes (C2) can boost the respiration of microbial communities, which prefer labile organic matter (Anesio et al., 2000). And protein-like substances (found in C3) have also been correlated with microbial respiration as well as community respiration in Canadian lakes (Cammack et al., 2004). They were also strongly linked to biodegradable DOC (Hood et al., 2009). Besides DOM, particular organic matter (POM) like seston, litter or wood could also fuel heterotrophic activity in streams (Rugenski et al., 2012; Vannote et al., 1980; Pusch and Schwoerbel, 1994). Unfortunately, POM was not examined in this study; thus a correlation analysis with this parameter is not possible. In addition, with the employed method we cannot distinguish between overlapping sources for the respiration of the stream community. However, the negative NEP values suggest that community respiration in all investigated streams was mainly fueled by allochthonous sources, which can also be POM.

\subsection{Implications of metabolism for the variability of DOM in space and time}

Many studies have found that the effect of land use on DOM composition is consistent across seasons, and it has been suggested that land use strongly regulates DOM composition in streams due to export regulation (Graeber et al., 2012; Stedmon and Markager, 2005; Petrone et al., 2011). However, if autotrophic processes are increasingly relevant for the DOM composition, it should also underlie land use changes and seasonal changes. We tested this hypothesis by considering the ratios of the PARAFAC components sorted according to land-use types and seasons (Fig. 6). A good predictor of seasonal changes seems to be ratios incorporating $\mathrm{C} 2$ because this is directly linked to GPP and could thus be affected by seasonal changes. In non-forestry streams, where $\mathrm{C} 2$ was suggested to be relevant, $\mathrm{C} 1: \mathrm{C} 2$ and $\mathrm{C} 3: \mathrm{C} 2$ values are lowest during the vegetation period (from spring to fall) and highest in winter. This suggests that in winter, when phototrophic processes are depleted, the role of al- lochthonous sources (groundwater and soil) increased. Such a seasonal effect was already shown for example by Minor et al. (2006), who observed higher autochthonous DOM signals in summer during a phytoplankton bloom in a shallow coastal bay. In forestry streams, where $\mathrm{C} 3$ seems to be more relevant, $\mathrm{C} 3$ : $\mathrm{C} 2$ decreased consistently from spring to winter and $\mathrm{C} 1: \mathrm{C} 2$ showed no clear variability. The higher discharge values in spring indicate a higher groundwater level in this period. Around summer the discharges and also the groundwater decreased rapidly in forestry streams (Table 1). This could diminish the ground water-stream water DOM flux, and therefore also $\mathrm{C} 3: \mathrm{C} 2$. In winter, when soils were frozen, the flux between groundwater and stream can be assumed to be depleted. Accordingly, the $\mathrm{C} 3: \mathrm{C} 2$ ratio in the forestry stream moves downwards to values close to 1 . The coupling between DOM quantity and quality and the hydrological input was recently demonstrated by Spencer et al. $(2008,2010)$. They showed a decrease of DOM concentration and a diminished labile DOM fraction with decreasing wetness for different streams. The decrease of this ratio could also be a result of increasing consumption of less refractory, allochthonous humic-like substances, but we were not able to detect this. An increasing heterotrophic consumption in the groundwater or the soil could also be a reason for this variability. To our knowledge, no studies addressing this complex mechanism have been published to date. We concluded that in forestry streams the seasonal variability of the groundwater was more relevant for DOM composition than stream metabolism. We also examined $\mathrm{C} 1: \mathrm{C} 3$, which was highly correlated to HIX, and could thus affect the heterotrophic turnover. The general increase of this ratio from spring to fall or winter in forestry and non-forestry streams, respectively, could be a result of changes in hydrological conditions (groundwater supply). Because there was no correlation between these components and metabolic parameters, we exclude the idea of an effect of autochthonous metabolic processes on this ratio. However, it can be maintained that there are clear signs of seasonal variability for DOM, even if the number of examined streams is low. This variability seems to be different for different land-use types ("forestry" and "non-forestry" streams). We speculate that future land use and climatic changes will affect DOM composition by irradiance changes and an increase of organic matter transport from the catchment which might both affect metabolism and thus DOM composition.

\section{Conclusions}

We demonstrated that DOM composition is linked to community metabolism in streams. The results obtained show a seasonal variability of the DOM composition and we were able to show that metabolism values change in parallel. In particular, GPP seems to be directly linked to autochthonously derived, less complex and less refractory 
humic-like substances. The impact of the different land-use types (forestry and non-forestry streams) on DOM composition is high, but also very complex. Based on our data we conclude that these differences are also driven by wholestream metabolism, in addition to pronounced effects coming from allochthonous sources. We hope that our study will stimulate further investigations addressing the role of primary production on DOM composition in streams.

Acknowledgements. For their assistance in the field and also in the laboratory we wish to thank the following students: Alana Steinbauer, Ulrike Köppe, Katrin Städtke, Florian Peters, Stefan Schade and Marian Präger. Special thanks to Erika Ruschak, and also to Ina Siebert, Marlies Wengler, Andrea Hoff, Kerstin Lerche, Ines Locker and Brunhilde Keller for their laboratory support. Romy Wild provided data for land use characterization. We also thank Sven Halbedel for assistance in the field, Dr. Desirée Dietrich and Anne Carney for proof-reading, Björn Gücker for his helpful hints when developing the two-station oxygen change technique for our metabolism studies, and Claire Woulds for improving an earlier version of this manuscript. The whole study was funded by the German Research Foundation (AN 777/2-1) and supported by TERENO (Terrestrial Environmental Observatories of the Helmholtz Association). Matthias Koschorreck provided different probes that were used in the field. The presented weather data are from the German Meteorological Service (DWD).

The service charges for this open access publication

have been covered by a Research Centre of the

Helmholtz Association.

Edited by: C. Woulds

\section{References}

Acuña, V., Giorgi, A., Muñoz, I., Uehlinger, U., and Sabater, S.: Flow extremes and benthic organic matter shape the metabolism of a headwater Mediterranean stream, Freshwater Biol., 49, 960971, doi:10.1111/j.1365-2427.2004.01239.x, 2004.

Acuña, V., Vilches, C., and Giorgi, A.: As productive and slow as a stream can be - the metabolism of a Pampean stream, J. N. Am. Benthol. Soc., 30, 71-83, doi:10.1899/09-082.1, 2010.

Anesio, A. M., Theil-Nielsen, J., and Graneli, W.: Bacterial growth on photochemically transformed leachates from aquatic and terrestrial primary producers, Microb. Ecol., 40, 200-208, 2000.

Bales, J. D. and Nardi, M. R.: Automated routines for calculating whole-stream metabolism-Theoretical background and user's guide, US Geological Survey Techniques and Methods, 33 pp., 2007.

Barrón, C., Apostolaki, E. T., and Duarte, C. M.: Dissolved organic carbon release by marine macrophytes, Biogeosciences Discuss., 9, 1529-1555, doi:10.5194/bgd-9-1529-2012, 2012.

Berggren, M., Laudon, H., Haei, M., Strom, L., and Jansson, M.: Efficient aquatic bacterial metabolism of dissolved low-molecularweight compounds from terrestrial sources, ISME J., 4, 408-416, doi:10.1038/ismej.2009.120, 2010.
Bernot, M. J., Sobota, D. J., Hall, R. O., Mulholland, P. J., Dodds, W. K., Webster, J. R., Tank, J. L., Ashkenas, L. R., Cooper, L. W., Dahm, C. N., Gregory, S. V., Grimm, N. B., Hamilton, S. K., Johnson, S. L., McDowell, W. H., Meyer, J. L., Peterson, B., Poole, G. C., Valett, H. M., Arango, C., Beaulieu, J. J., Burgin, A. J., Crenshaw, C., Helton, A. M., Johnson, L., Merriam, J., Niederlehner, B. R., O’Brien, J. M., Potter, J. D., Sheibley, R. W., Thomas, S. M., and Wilson, K.: Inter-regional comparison of land-use effects on stream metabolism, Freshwater Biol., 55, 1874-1890, doi:10.1111/j.1365-2427.2010.02422.x, 2010.

Blann, K. L., Anderson, J. L., Sands, G. R., and Vondracek, B.: Effects of Agricultural Drainage on Aquatic Ecosystems: A Review, Crit. Rev. Env. Sci. Tec., 39, 909-1001, doi:10.1080/10643380801977966, 2009.

Cammack, W. K. L., Kalff, J., Prairie, Y. T., and Smith, E. M.: Fluorescent dissolved organic matter in lakes: Relationships with heterotrophic metabolism, Limnol. Oceanogr., 49, 2034-2045, 2004.

Demars, B. O. L., Manson, J. R., Ólafsson, J. S., Gislason, G. M., Gudmundsdóttir, R., Woodward, G., Yvon-Durocher, G., Perkins, D. M., Reiss, J., Pichler, D., rasmussen, J. J., and Friberg, N.: Temperature and the metabolic balance of streams, Freshwater Biol., 56, 1106-1121, 2011.

Elmore, H. L. and West, W. F.: Effect of water temperature on stream reaeration, J. Am. Soc. Civ. Eng., 87, 59-71, 1961.

Fellman, J. B., Hood, E., and Spencer, R. G. M.: Fluorescence spectroscopy opens new windows into dissolved organic matter dynamics in freshwater ecosystems: A review, Limnol. Oceanogr., 55, 2452-2462, doi:10.4319/lo.2010.55.6.2452, 2010.

Finlay, J. C., Hood, J. M., Limm, M. P., Power, M. E., Schade, J. D., and Welter, J. R.: Light-mediated thresholds in stream-water nutrient composition in a river network, Ecology, 92, 140-150, 2011.

Gordon, D. N., McMahon, T. A., Finlay, B. L., Gippel, C. J., and Nathan, R. J. (Eds.): Stream hydrology: an introduction for ecologists, West Sussex, John Wiley \& Sons Ltd, 2008.

Graeber, D., Gelbrecht, J., Pusch, M. T., Anlanger, C., and von Schiller, D.: Agriculture has changed the amount and composition of dissolved organic matter in Central European headwater streams, Sci. Total Environ., 438, 435-446, doi:10.1016/j.scitotenv.2012.08.087, 2012.

Gücker, B., BoËChat, I. G., and Giani, A.: Impacts of agricultural land use on ecosystem structure and whole-stream metabolism of tropical Cerrado streams, Freshwater Biol., 54, 2069-2085, doi:10.1111/j.1365-2427.2008.02069.x, 2009.

Hall, R. O. and Tank, J. L.: Correcting whole-stream estimates of metabolism for groundwater input, Limnol. Oceanogr.-Methods, 3, 222-229, 2005.

Hauer, F. R. and Lamberti, G. A. (Eds.): Methods in Stream Ecology, Tokyo, Elservier, 2007.

Hood, E., Fellman, J., Spencer, R. G. M., Hernes, P. J., Edwards, R., D'Amore, D., and Scott, D.: Glaciers as a source of ancient and labile organic matter to the marine environment, Nature, 462, 1044-U1100, doi:10.1038/Nature08580, 2009.

Houser, J. N., Mulholland, P. J., and Maloney, K. O.: Catchment disturbance and stream metabolism: patterns in ecosystem respiration and gross primary production along a gradient of upland soil and vegetation disturbance, J. N. Am. Benthol. Soc., 24, 538$552,2005$. 
Hudson, N., Baker, A., and Reynolds, D.: Fluorescence analysis of dissolved organic matter in natural, waste and polluted waters A review, River Res. Appl., 23, 631-649, doi:10.1002/Rra.1005, 2007.

Huguet, A., Vacher, L., Relexans, S., Saubusse, S., Froidefond, J. M., and Parlanti, E.: Properties of fluorescent dissolved organic matter in the Gironde Estuary, Org. Geochem., 40, 706-719, doi:10.1016/j.orggeochem.2009.03.002, 2009.

Inamdar, S., Finger, N., Singh, S., Mitchell, M., Levia, D., Bais, H., Scott, D., and McHale, P.: Dissolved organic matter (DOM) concentration and quality in a forested mid-Atlantic watershed, USA, Biogeochemistry, 108, 55-76, doi:10.1007/s10533-0119572-4, 2012.

Jaffé, R., McKnight, D., Maie, N., Cory, R., McDowell, W. H., and Campbell, J. L.: Spatial and temporal variations in DOM composition in ecosystems: The importance of long-term monitoring of optical properties, J. Geophys. Res.-Biogeo., 113, G04032, doi:10.1029/2008jg000683, 2008.

Lapierre, J. F. and Frenette, J. J.: Effects of macrophytes and terrestrial inputs on fluorescent dissolved organic matter in a large river system, Aquat. Sci., 71, 15-24, doi:10.1007/s00027-009-9133-2, 2009.

Marcarelli, A. M., Baxter, C. V., Mineau, M. M., and Hall, R. O.: Quantity and quality: unifying food web and ecosystem perspectives on the role of resource subsidies in freshwaters, Ecology, 92, 1215-1225, 2011.

Matheson, F. E., Quinn, J. M., and Martin, M. L.: Effects of irradiance on diel and seasonal patterns of nutrient uptake by stream periphyton, Freshwater Biol., 57, 1617-1630, doi:10.1111/j.1365-2427.2012.02822.x, 2012.

McKnight, D. M.: Spectrofluorometric characterization of dissolved organic matter for indication of precursor organic material and aromaticity, Limnol. Oceanogr., 46, 38-48, 2001.

Minor, E. C., Simjouw, J. P., and Mulholland, M. R.: Seasonal variations in dissolved organic carbon concentrations and characteristics in a shallow coastal bay, Mar. Chem., 101, 166-179, doi:10.1016/j.marchem.2006.02.005, 2006.

Minshall, G. W.: Autotrophy in Stream Ecosystems, Bioscience, 28, 767-770, 1978.

Mobed, J. J., Hemmingsen, S. L., Autry, J. L., and McGown, L. B.: Fluorescence characterization of IHSS humic substances: Total luminescence spectra with absorbance correction, Environ. Sci. Technol., 30, 3061-3065, doi:10.1021/Es9601321, 1996.

Mueller, K. K., Fortin, C., and Campbell, P. G. C.: Spatial Variation in the Optical Properties of Dissolved Organic Matter (DOM) in Lakes on the Canadian Precambrian Shield and Links to Watershed Characteristics, Aquat. Geochem., 18, 2144, doi:10.1007/s10498-011-9147-y, 2012.

Mulholland, P. J., Fellows, C. S., Tank, J. L., Grimm, N. B., Webster, J. R., Hamilton, S. K., Marti, E., Ashkenas, L., Bowden, W. B., Dodds, W. K., McDowell, W. H., Paul, M. J., and Peterson, B. J.: Inter-biome comparison of factors controlling stream metabolism, Freshwater Biol., 46, 1503-1517, 2001.

Mulholland, P. J., Houser, J. N., and Maloney, K. O.: Stream diurnal dissolved oxygen profiles as indicators of in-stream metabolism and disturbance effects: Fort Benning as a case study, Ecol. Indic., 5, 243-252, doi:10.1016/j.ecolind.2005.03.004, 2005.

Odum, H. T.: Primary Production in Flowing Waters, Limnol. Oceanogr., 1, 102-117, 1956.
Ogawa, H., Amagai, Y., Koike, I., Kaiser, K., and Benner, R.: Production of refractory dissolved organic matter by bacteria, Science, 292, 917-920, 2001.

Ohno, T.: Fluorescence inner-filtering correction for determining the humification index of dissolved organic matter, Environ. Sci. Technol., 36, 742-746, doi:10.1021/Es0155276, 2002.

Ohno, T., Fernandez, I. J., Hiradate, S., and Sherman, J. F.: Effects of soil acidification and forest type on water soluble soil organic matter properties, Geoderma, 140, 176-187, doi:10.1016/j.geoderma.2007.04.004, 2007.

Parlanti, E., Worz, K., Geoffroy, L., and Lamotte, M.: Dissolved organic matter fluorescence spectroscopy as a tool to estimate biological activity in a coastal zone submitted to anthropogenic inputs, Org. Geochem., 31, 1765-1781, 2000.

Pusch, M. and Schwoerbel, J.: Community Respiration in Hyporheic Sediments of a Mountain Stream (Steina, Black-Forest), Arch. Hydrobiol., 130, 35-52, 1994.

Rathbun, R. E., Stephens, D. W., Schultz, D. J., and Tai, D. Y.: Laboratory studies of gas tracers for reaeration, P. Am. Soc. Civ. Eng., 104, 215-229, 1978.

Royer, T. V. and David, M. B.: Export of dissolved organic carbon from agricultural streams in Illinois, USA, Aquat. Sci., 67, 465471, 2005.

Rugenski, A. T., Murria, C., and Whiles, M. R.: Tadpoles enhance microbial activity and leaf decomposition in a neotropical headwater stream, Freshwater Biol., 57, 1904-1913, doi:10.1111/j.1365-2427.2012.02853.x, 2012.

Spencer, R. G. M., Aiken, G. R., Wickland, K. P., Striegl, R. G., and Hernes, P. J.: Seasonal and spatial variability in dissolved organic matter quantity and composition from the Yukon River basin, Alaska, Global Biogeochem. Cy., 22, Gb4002, doi:10.1029/2008gb003231, 2008.

Spencer, R. G. M., Hernes, P. J., Ruf, R., Baker, A., Dyda, R. Y., Stubbins, A., and Six, J.: Temporal controls on dissolved organic matter and lignin biogeochemistry in a pristine tropical river, Democratic Republic of Congo, J. Geophys. Res.-Biogeo., 115, G03013, doi:10.1029/2009jg001180, 2010.

Stedmon, C. A. and Bro, R.: Characterizing dissolved organic matter fluorescence with parallel factor analysis: a tutorial, Limnol. Oceanogr.-Methods, 6, 572-579, 2008.

Stedmon, C. A., Markager, S., Sondergaard, M., Vang, T., Laubel, A., Borch, N. H., and Windelin, A.: Dissolved organic matter (DOM) export to a temperate estuary: Seasonal variations and implications of land use, Estuar. Coast, 29, 388-400, 2006.

Stepanauskas, R. N., Farjalla, V. F., Tranvik, L. J., Svensson, J. M., Esteves, F. A., and Granéli, W.: Bioavailability and sources of DOC and DON in macrophyte stands of a tropical coastal lake, Hydrobiologia, 436, 241-248, doi:10.1023/a:1026537905947, 2000.

Tank, J. L., Rosi-Marshall, E. J., Griffiths, N. A., Entrekin, S. A., and Stephen, M. L.: A review of allochthonous organic matter dynamics and metabolism in streams, J. N. Am. Benthol. Soc., 29, 118-146, doi:10.1899/08-170.1, 2010.

Vannote, R. L., Minshall, G. W., Cummins, K. W., Sedell, J. R., and Cushing, C. E.: River Continuum Concept, Can. J. Fish. Aquat. Sci., 37, 130-137, doi:10.1139/F80-017, 1980.

Wetzel, R. G.: Gradient-Dominated Ecosystems - Sources and Regulatory Functions of Dissolved Organic-Matter in Fresh-Water Ecosystems, Hydrobiologia, 229, 181-198, 1992. 
Wetzel, R. G., Hatcher, P. G., and Bianchi, T. S.: Natural photolysis by ultraviolet irradiance of recalcitrant dissolved organic matter to simple substrates for rapid bacterial metabolism, Limnol. Oceanogr., 40, 1369-1380, 1995.

Wickland, K. P., Neff, J. C., and Aiken, G. R.: Dissolved organic carbon in Alaskan boreal forest: Sources, chemical characteristics, and biodegradability, Ecosystems, 10, 1323-1340, doi:10.1007/s 10021-007-9101-4, 2007.

Williams, C. J., Yamashita, Y., Wilson, H. F., Jaffe, R., and Xenopoulos, M. A.: Unraveling the role of land use and microbial activity in shaping dissolved organic matter characteristics in stream ecosystems, Limnol. Oceanogr., 55, 1159-1171, doi:10.4319/lo.2010.55.3.1159, 2010.
Wilson, H. F. and Xenopoulos, M. A.: Effects of agricultural land use on the composition of fluvial dissolved organic matter, Nat. Geosci., 2, 37-41, 2009.

Young, R. G. and Huryn, A. D.: Effects of land use on stream metabolism and organic matter turnover, Ecol. Appl., 9, 13591376, 1999.

Zsolnay, A., Baigar, E., Jimenez, M., Steinweg, B., and Saccomandi, F.: Differentiating with fluorescence spectroscopy the sources of dissolved organic matter in soils subjected to drying, Chemosphere, 38, 45-50, 1999. 